\title{
STUDIES ON THE CONCENTRATION AND INTRINSIC VISCOSITY OF HYALURONIC ACID IN SYNOVIAL FLUIDS OF PATIENTS WITH RHEUMATIC DISEASES*
}

BY

\author{
CHESTER T. STAFFORD, WILLIAM NIEDERMEIER, HOWARD L. HOLLEY, \\ AND WARD PIGMAN $\dagger$ \\ From the Division of Rheumatic Diseases, Departments of Medicine and Biochemistry, \\ University of Alabama Medical Center, Birmingham, Alabama
}

The observation that the relative viscosity of synovial fluid obtained from patients with joint effusion associated with connective tissue diseases is decreased has stimulated a number of investigations directed towards the characterization of the nature of this alteration. Since the relative viscosity of synovial fluid is a function both of the concentration of hyaluronic acid and of its degree of polymerization elucidation of this problem is predicated on the determination of both of these parameters. Earlier studies have dealt primarily with the differences in hyaluronic acid concentration (Decker, McGuckin, McKenzie, and Slocumb, 1959), or with the comparison of relative viscosities at an arbitrarily chosen concentration (Fletcher, Jacobs, and Markham, 1955). These results indicated that the hyaluronic acid concentration is decreased and suggested that the polysaccharide was depolymerized in synovial fluids obtained from patients with rheumatic diseases.

Sundblad (1953) later demonstrated the usefulness of intrinsic viscosity determinations as a measure of the degree of polymerization of hyaluronic acid in human synovial fluid. He calculated the hyaluronic acid concentration of synovial fluid from the glucosamine concentration, which was determined by a modification of the Elson-Morgan procedure, after hyaluronidase digestion followed by trichloroacetic acid precipitation of the proteins. The intrinsic viscosity was calculated from the results of a series of relative viscosity determinations made at different dilutions of the fluid in a phosphate buffer, at $\mathrm{pH}$ $7 \cdot 0$, ionic strength $0.20(0.08$ phosphate +0.12 sodium chloride), and a temperature of $37^{\circ} \mathrm{C}$. Balazs and Sundblad (1959) have shown that the presence of serum proteins does not appreciably influence the viscous behaviour of hyaluronic acid.

* Supported in part by U.S. Public Health Service Grants AM 03555, AM 04911, and AM 04619.

$\dagger$ Department of Biochemistry, New York Medical College, Fifth Avenue at 106th Street, New York, N.Y., U.S.A.
Bollet (1956) also studied hyaluronic acid concentration and intrinsic viscosity of synovial fluid in subjects with no history or evidence of rheumatic disease, and compared these parameters with those obtained from patients with joint diseases. The hyaluronic acid concentration of the fluid was determined by a modification of the Dische (1947) carbazole reaction for uronic acids after removal of most of the protein by chloroform denaturation and extraction. The intrinsic viscosity was determined by a procedure similar to that used by Sundblad (1953), with the exception that the relative viscosity was determined in a buffer consisting of $0.05 \mathrm{M}$ phosphate and $0.0125 \mathrm{M}$ sodium chloride, $\mathrm{pH} 7 \cdot 0$, at $37^{\circ} \mathrm{C}$.

The results obtained by Bollet (1956) are compared with those reported by Sundblad in Table I (opposite).

An explanation of the discrepancies in the results of these two reports is not immediately apparent. It has been demonstrated (Pigman, Hawkins, Gramling Rizvi, and Holley, 1960), however, that hyaluronic acid is degraded slowly in the presence of phosphate ions but is stable in veronal buffers. Since phosphate buffers were used in both these studies, we felt that more definitive results might be obtained in a study that avoided the use of these buffers, as well as other materials and conditions known to promote degradation of the polysaccharide.

In the previously reported studies the "control" synovial fluid specimens were obtained post mortem. In the present studies the results obtained from synovial fluid specimens from patients with rheumatic diseases were compared with biopsy specimens from "normal" volunteers as well as those obtained post mortem.

\section{Materials and Methods}

Materials.-Synovial fluid was aspirated from the knee joints of 67 patients with joint effusion seen in the Rheu- 
TABLE I

DATA PREVIOUSLY REPORTED ON AVERAGE HYALURONIC ACID CONCENTRATION (H.A.C.) AND INTRINSIC VISCOSITY [ $\eta$ ] OF HUMAN SYNOVIAL FLUIDS

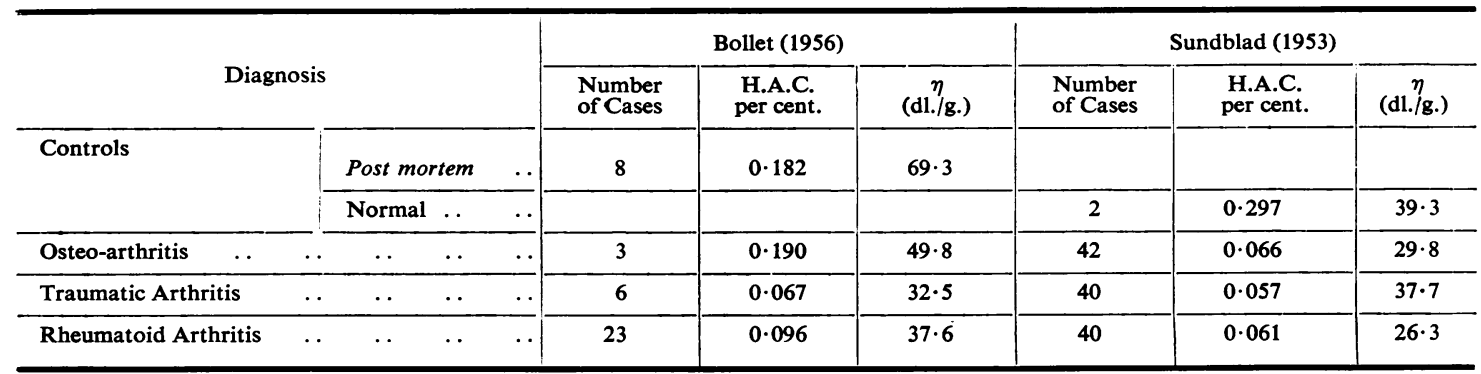

matic Disease Clinic, University Hospital and Hillman Clinic, University of Alabama Medical Center. These patients were diagnosed as cases of osteo-arthritis (19); peripheral rheumatoid arthritis (22)*; arthritis of traumatic origin (15); ankylosing spondylitis (2); Baker's cyst (2); gout (2); systemic lupus erythematosus (3); monoarticular synovitis of unknown aetiology (3).

Specimens of synovial fluid obtained from thirteen patients at autopsy and from eight apparently healthy male volunteers with no history or clinical evidence of rheumatic disease were used as controls.

All fluids were stored at $2^{\circ} \mathrm{C}$. without preservative until ready for study. The samples were centrifuged for $30 \mathrm{~min}$. at 25,000 r.p.m. in a refrigerated ultracentrifuge and were dialysed overnight against veronal buffer $\mathrm{pH}$ $8 \cdot 6$ and ionic concentration $0 \cdot 1$ ).

Hyaluronic Acid Determination.--Measurements of hyaluronic acid concentration were carried out on mucin clots prepared by the addition of an equal volume of 5 per cent. acetic acid to $1 \mathrm{ml}$. aliquots of each sample of synovial fluid. It has been demonstrated (Ogston and Stanier, 1953) that the hyaluronic acid is quantitatively recovered in the clot by this procedure, even in fluids that have been partially digested with hyaluronidase. The mucin clots were separated from the supernatant fluid by centrifugation, washed with 5 per cent. acetic acid, and dissolved in $1 \mathrm{ml} .0 \cdot 5 \mathrm{~N}$ sodium hydroxide. Each sample was diluted to $10 \mathrm{ml}$. with distilled water. A $1 \mathrm{ml}$. aliquot of the dilution was used to determine the concentration of glucuronic acid using a modification of the carbazole method by Dische (1947). Most of the protein remained in the supernatant fluid (Pigman, Gramling, Platt, and Holley, 1959), thus minimizing the problem of extraneous colour which develops with proteins in the presence of sulphuric acid under the conditions of the Dische (1947) reaction. To correct for the small amount of protein complexed with the hyaluronic acid in the mucin clot, a

* These patients fulfilled the criteria set forth by the American Rheumatism Association for classical and definite rheumatoid arthritis (Ropes, Bennett, Cobb, Jacox, and Jessar, 1957), and were also classified as to stage and functional status of the disease (Steinbrocker, Traeger, and Batterman, 1949). blank determination was performed on each specimen which was treated the same way as the sample, with the exception that $0 \cdot 1 \mathrm{ml}$. ethanol was substituted for the colour reagent.

A reference curve was prepared using anhydrous glucuronic acid as the standard. The concentration of glucuronic acid was read directly from this curve after correcting for the blank. Hyaluronic acid concentrations were calculated from the glucuronic acid determinations based on the ratio of the molecular weight of the two substances.

Viscosity Determinations.-These were performed on serial dilutions of each sample of synovial fluid in veronal buffer, $\mathrm{pH} 8 \cdot 6, \mu 0 \cdot 1$, in a constant temperature water bath at $30^{\circ} \mathrm{C}$. with a Cannon-Manning semi-micro viscometer which had a total capacity of $0.2 \mathrm{ml}$. The specific viscosity of each dilution was calculated by comparing its rate of flow in the viscometer with that of veronal buffer. Intrinsic viscosity was determined by plotting specific viscosity against the ratio of specific viscosity to concentration for the serial dilutions and extrapolating to infinite dilution according to the method of Sundblad (1953). A representative graph is shown in Fig. 1.

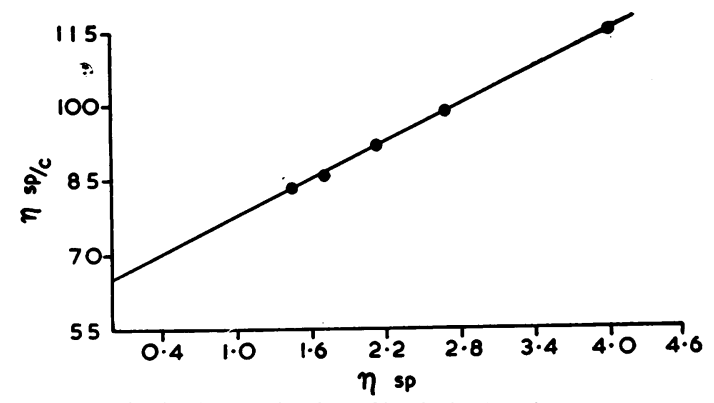

Fig. 1.-Determination of intrinsic viscosity.

Effect of Storage of Synovial Fluid at $2^{\circ}$ C. on Intrinsic Viscosity.-To determine whether changes in the degree of polymerization of hyaluronic acid occurred during 
storage of synovial fluid at $2^{\circ} \mathrm{C}$., intrinsic viscosity determinations were repeated on the same specimen after various periods of storage. As indicated by the data in Table II, there were no significant changes in intrinsic viscosity in any of the specimens after storage for periods up to 468 days.

\section{Results}

Intrinsic Viscosity (Fig. 2, opposite).-The mean intrinsic viscosity ( \pm S.D.) for the eight specimens of synovial fluid from the "normal" volunteers and the thirteen specimens of post mortem synovial fluid were $81 \pm 6.8 \mathrm{dl}$./g. and $73 \pm 11.0 \mathrm{dl}$./g. respectively; this was higher than the mean for any of the groups of pathological specimens except that from three patients with systemic lupus erythematosus. The mean intrinsic viscosities for synovial fluid from patients with osteo-arthritis, rheumatoid arthritis, and traumatic arthritis were $56 \pm 13 \cdot 3,54 \pm 11 \cdot 0$, and $45 \pm 8 \cdot 7 \mathrm{dl}$./g. respectively. Statistical evaluation by the Student " $t$ " test indicated that these mean values were all significantly less $(P<0.01)$ than that for either the "normal" controls or the post mortem specimens. The mean intrinsic viscosity of the specimens from patients with traumatic arthritis was significantly less $(P<0.01)$ than that of the specimens from patients with either rheumatoid arthritis or osteo-arthritis. The small difference between the means of the specimens obtained from patients with rheumatoid arthritis and osteo-arthritis was not significant $(P>0.05)$. Although only a limited number of specimens were analysed from patients with gout, idiopathic monoarticular synovitis, Baker's cyst, and ankylosing spondylitis, the mean intrinsic viscosities for these groups were less than those of the "normal" or post mortem controls, and were comparable to those of patients with osteoarthritis, rheumatoid arthritis, and traumatic arthritis. The mean intrinsic viscosity of synovial fluid from three patients with systemic lupus erythematosus was $81 \mathrm{dl} . / \mathrm{g}$. - the highest mean value obtained for any of the groups of pathological specimens analysed. Because of the small sample size, it was not significantly different, however, from the mean for the "normal" or post mortem specimens.

Hyaluronic Acid Concentration.-The mean hyaluronic acid concentration ( \pm S.D.) of synovial fluids obtained from the "normal" volunteers (Fig. 3 , opposite) was 0.41 per cent. $\pm 0 \cdot 10$, significantly greater $(P<0.01)$ than the mean of $0.24 \pm 0.09$ obtained for the specimens collected post mortem. Both these mean values were significantly greater $(P<0.01)$ than those obtained for synovial fluid from patients with osteo-arthritis, rheumatoid arthritis, and traumatic arthritis $(0 \cdot 12$ per cent. \pm $0.47,0.07$ per cent. \pm 0.029 , and 0.11 per cent. \pm 0.042 respectively).

The mean hyaluronic acid concentration of the specimens from patients with rheumatoid arthritis was significantly less $(P<0.01)$ than that of the specimens from patients with osteo-arthritis or traumatic arthritis. The small difference between the means for the specimens from patients with osteo-arthritis and traumatic arthritis was not statistically significant. The mean hyaluronic acid concentrations in synovial fluids from patients with gout, local synovitis, Baker's cyst, and ankylosing spondylitis were also found to be less than that of the post mortem control specimens.

\section{Discussion}

The mean hyaluronic acid concentration of post mortem synovial fluid was markedly lower than that in the group of "normal" volunteers. This difference probably reflects a post mortem change which may result in dilution of the synovial fluid. The relatively high intrinsic viscosity of the post mortem fluids indicates that this dilution is not accompanied by appreciable degradation of the hyaluronic acid.

The results indicate that the relatively low viscosity of synovial fluid in patients with rheumatic diseases

TABLE II

EFFECT OF STORAGE AT $2^{\circ}$ C. ON HYALURONIC ACID CONCENTRATION (H.A.C.) AND INTRINSIC VISCOSITY $[\eta]$ OF HUMAN SYNOVIAL FLUID

\begin{tabular}{|c|c|c|c|c|c|c|}
\hline $\begin{array}{l}\text { Specimen } \\
\text { No. }\end{array}$ & Diagnosis & & H.A.C. (g. $/ 100 \mathrm{ml}$.) & (dl./g. $)^{\eta}$ Initial & $\begin{array}{c}\text { Time of Storage } \\
\text { (days) }\end{array}$ & $\begin{array}{c}\eta(\mathrm{dl} . / \mathrm{g} .) \\
\text { After Storage }\end{array}$ \\
\hline A319 & Traumatic Arthritis ... & $\cdots$ & $0 \cdot 129$ & 37 & 17 & 36 \\
\hline B-47 & Rheumatoid Arthritis & $\ldots$ & 0.083 & 60 & 468 & 60 \\
\hline A460 & Osteo-arthritis & $\cdots$ & $0 \cdot 110$ & 49 & 268 & 47 \\
\hline A879 & Rheumatoid Arthritis & $\ldots \quad \ldots$ & 0.084 & 64 & 108 & 65 \\
\hline
\end{tabular}




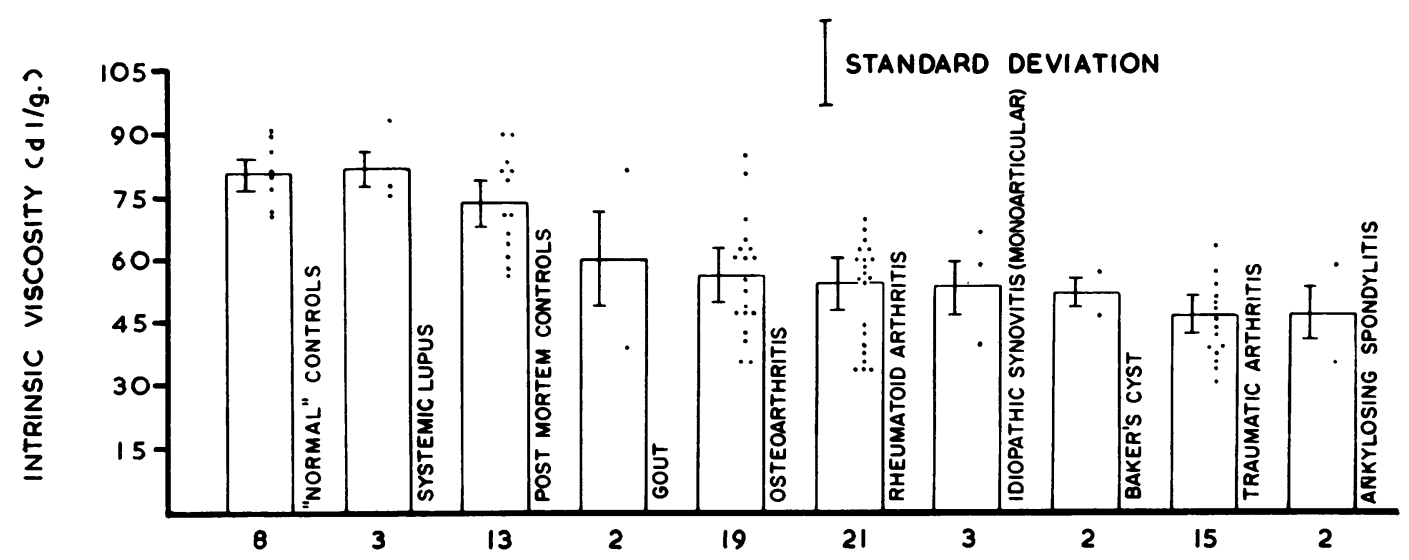

Fig. 2.-Intrinsic viscosity of synovial fluid in various diseases.

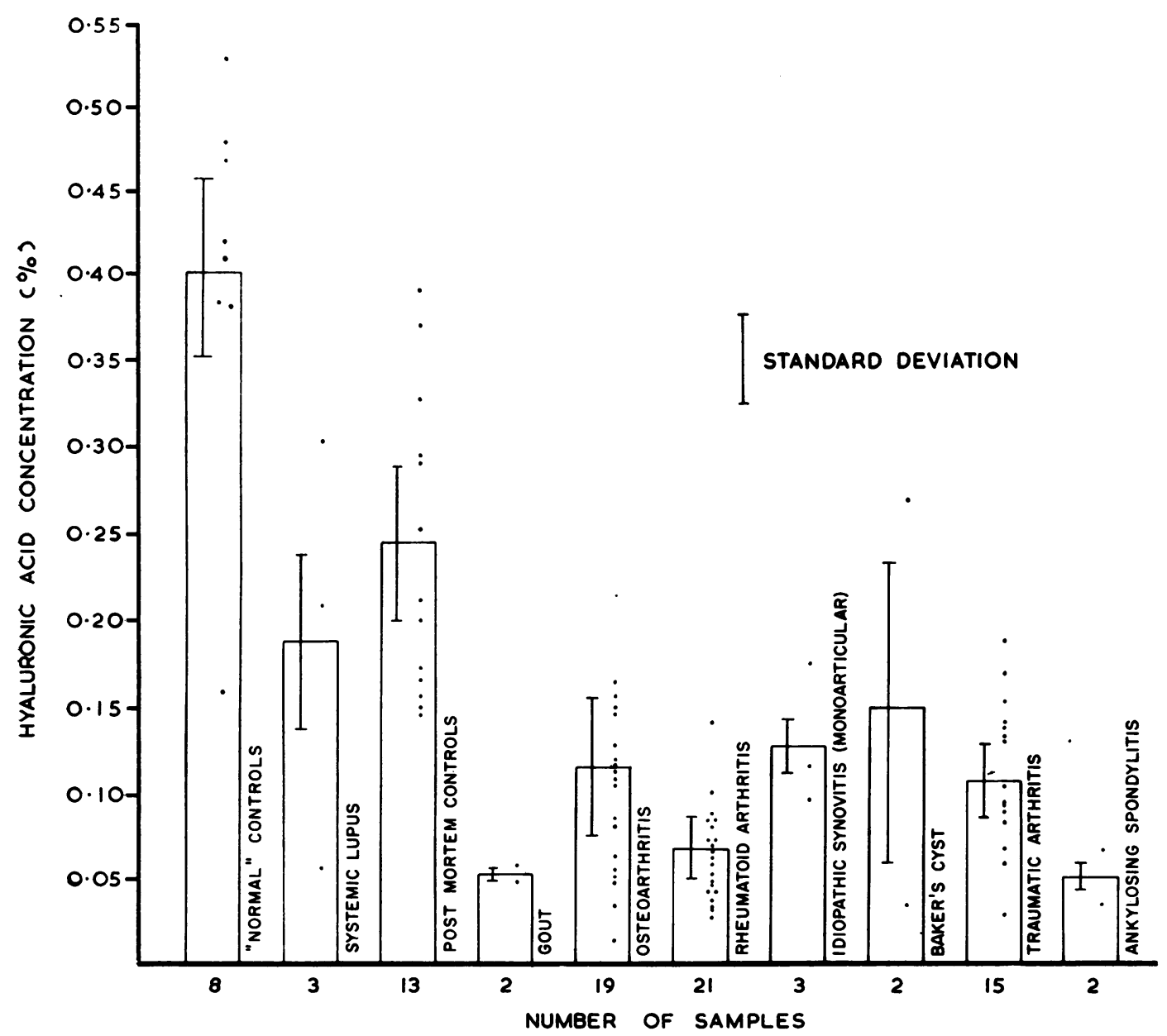

Fig. 3.-Concentration of hyaluronic acid in synovial fluid in various diseases. 
is caused by a decrease in both concentration and degree of polymerization of hyaluronic acid. It would appear likely that the decrease in concentration of the polysaccharide may be due to dilution of the fluid. The depolymerization may be due to an increased concentration of protein in the synovial fluid (Fletcher, Jacobs, and Markham, 1955) or to other degrading factors present in blood serum that might gain access to the synovial space though an increased permeability of the synovial membrane. That certain components of blood serum cause depolymerization of hyaluronic acid when incubated with it in vitro has been previously demonstrated (Pigman, Rizvi, and Holley, 1961).

The observations on synovial fluid from patients with systemic lupus erythematosus (SLE) agree well with those of Ropes and Bauer (1953), who noted that synovial fluid from patients with this disease had a low glucosamine concentration but that the fluid was usually "very viscous" and formed a "firm, ropy" mucin clot after acidification. Bollet (1956) also observed that the mean intrinsic viscosity of synovial fluid from patients with SLE was higher than that of any other group of patients studied with the exception of those with pyogenic arthritis.

The results of the present study are qualitatively similar to those previously reported by Bollet (1956). The values of the intrinsic viscosity determinations were slightly higher, but paralleled those which he reported, in that the lowest mean values were seen in traumatic arthritis, and the next lowest in rheumatoid arthritis and osteo-arthritis.

The reduction in hyaluronic acid concentration that accompanies rheumatic diseases was found to be even greater than indicated by the previous studies in which post mortem specimens of synovial fluid were used as controls, since the hyaluronic acid concentration in synovial fluid collected post mortem is less than in fluid from apparently normal healthy individuals.

Of the 21 patients with a diagnosis of active rheumatoid arthritis, eight were receiving oral corticosteroids, one weekly injections of gold salts, and thirteen oral salicylates. No correlation could be found between the therapeutic agent and hyaluronic acid concentration or intrinsic viscosity of the synovial fluid, although other investigators (Sundblad, 1953;Egelius, and Jonsson, 1954; Jessar, Ganzell, and Ragan, 1953) have reported an increase in intrinsic viscosity after suppression of the inflammation by oral or intra-articular corticosteroids. In earlier studies from this laboratory (Platt, Holley, and Pigman, 1957), it was observed that the electrophoretic mobility of the protein in synovial fluid of patients with rheumatoid arthritis returned towards normal after intra-articular corticosteroids, which suggested that this treatment effected an increase in intrinsic viscosity of the synovial fluid. The failure to observe higher intrinsic viscosities in synovial fluids from patients receiving corticosteroids in the present study may be due to the fact that only low maintenance doses of the drug were being used.

In addition, no correlation could be demonstrated between the alterations in the synovial fluid and grade of functional capacity, stage of severity, or duration of rheumatoid arthritis. These findings would appear to confirm the observations of Bollet (1956), who was unable to demonstrate any correlation between alterations in synovial fluid and the clinical aspects of the disease. He likewise found that oral corticosteroids had no appreciable effect on the intrinsic viscosity of the synovial fluid in patients with rheumatoid arthritis.

\section{Summary}

The concentration and intrinsic viscosity of hyaluronic acid were determined in synovial fluids from the knee joints of 67 patients with rheumatic diseases. The mean values were compared with those obtained for synovial fluids from eight "normal" volunteers and from thirteen post mortem specimens from subjects without evidence of joint disease. The intrinsic viscosities and concentrations of hyaluronic acid were both decreased in synovial fluids from patients with osteo-arthritis, traumatic arthritis, and rheumatoid arthritis.

The intrinsic viscosity of synovial fluids from patients with traumatic arthritis was less than that from patients with osteo-arthritis or rheumatoid arthritis. No significant difference in intrinsic viscosity could be found between the two latter groups. The hyaluronic acid concentration of synovial fluids from patients with rheumatoid arthritis was less than that from patients with osteo-arthritis or traumatic arthritis, but there was no significant difference between the two latter groups.

No correlation could be demonstrated between the hyaluronic acid concentration or intrinsic viscosity of synovial fluid and the clinical status of the disease in patients with rheumatoid arthritis.

The intrinsic viscosity of post mortem synovial fluid was not significantly different from that of "normal" synovial fluid, but the concentration of hyaluronic acid in post mortem synovial fluids was markedly less than that in those from "normal" volunteers.

The authors wish to thank Miss Esther Lacey for her competent technical assistance. 


\section{REFERENCES}

Balazs, E. A., and Sundblad, L. (1959). Acta Soc. Med. upsalien, 64, 137.

Bollet, A. J. (1956). J. Lab. clin. Med., 48, 721.

Decker, B., McGuckin, W. F., McKenzie, B. F., and Slocumb, C. H. (1959). Clin. Chem., 5, 465.

Dische, Z. (1947). J. biol. Chem., 167, 189.

Fletcher, E., Jacobs, J. H., and Markham, R. L. (1955). Clin. Sci., 14, 653.

Jessar, R. A., Ganzell, M. A., and Ragan, C. (1953). J. clin. Invest., 32,480.

Ogston, A. G., and Stanier, J. E. (1953). J. Physiol. (Lond.), 119, 253.

Pigman, W., Gramling, E., Platt, D., and Holley, H. L. (1959). Biochem. J., 71, 201.

-, Hawkins, W., Gramling, E., Rizvi, S., and Holley, H. L. (1960). Arch. Biochem., 89, 184.

- -, Rizvi, S., and Holley, H. L. (1961). Arthr. and Rheum., 4, 240.

Platt, D., Holley, H. L., and Pigman, W. (1957). J. Lab. clin. Med., 49, 762.

Ropes, M. W., and Bauer, W. (1953). "Synovial Fluid Changes in Joint Disease." Harvard University Press, Cambridge, Mass.

- - Bennett, G. A., Cobb, S., Jacox, R., and Jessar, R. A. (1957). J. chron. Dis., 5, 630.

Steinbrocker, O., Traeger, C. H., and Batterman, R. C. (1949). J. Amer. med. Ass., 140, 659.

Sundblad, L. (1953). Acta Soc. Med. upsalien, 58, 113.

Egelius, N., and Jonsson, E. (1954). Scand. J. clin. Lab. Invest., 6, 295.

Etudes sur la concentration et la viscosité intrinsèque de l'acide hyaluronique dans le liquide synovial des sujets atteints de maladies rhumatismales

\section{RÉSUMÉ}

On détermina la concentration et la viscosité intrinsèque de l'acide hyaluronique dans le liquide synovial provenant de genoux de 67 malades atteints de différentes maladies rhumatismales. Les valeurs moyennes furent comparées à celles obtenues pour le liquide synovial de huit "volontaires" normaux et de treize prélèvements d'autopsie des sujets qui ne présentaient pas de signes de maladie articulaire. $\mathrm{La}$ viscosité intrinsèque et la concentration de l'acide hyaluronique se trouvaient diminuées dans le liquide synovial des malades atteints d'ostéoarthrite, d'arthrite traumatique et d'arthrite rhumatismale.

La viscosité intrinsèque du liquide synovial des malades atteints d'arthrite traumatique était inférieure à celle des malades atteints d'ostéoarthrite ou d'arthrite rhumatismale. On ne trouva pas de différence significative entre les deux derniers groupes en ce qui concerne la viscosité intrinsèque. La concentration de l'acide hyaluronique dans le liquide synovial des malades atteints d'arthrite rhumatismale était inférieure à celle des malades atteints d'ostéoarthrite ou d'arthrite traumatique, mais il n'y avait pas de différence significative entre ces deux derniers groupes.

On ne trouva pas de correlation entre la concentration de l'acide hyaluronique ou la viscosité intrinsèque du liquide synovial et l'état clinique de la maladie chez des malades atteints d'arthrite rhumatismale.

La viscosité intrinsèque des liquides synoviaux prélévés à l'autopsie ne se distinguait pas appréciablement de celle des liquides synoviaux "normaux", mais la concentration de l'acide hyaluronique des liquides synoviaux des cadavres était appréciablement inférieure à celle trouvée chez des volontaires "normaux".

\section{Investigaciones sobre la concentración y la viscosidad intrínseca del ácido hialúronico en el líquido sinovial de pacientes con enfermedades reumáticas}

\section{SUMARIO}

Se determinaron la concentración y la viscosidad intrínseca del ácido hialurónico en el líquido sinovial de articulaciones de la rodilla de 67 pacientes con varias enfermedades reumáticas. Los valores medios fueron comparados con los obtenidos para el líquido sinovial de ocho "voluntarios" normales y de trece especimenes de autopsia de sujetos que no presentaron evidencia de enfermedad articular. La viscosidad intrínseca y la concentración del ácido hialurónico se vieron disminuidos en el líquido sinovial de los enfermos con osteoartritis, artritis traumática y artritis reumatoide.

La viscosidad intrínseca del líquido sinovial de enfermos con artritis traumática fué inferior a la de los enfermos con osteoartritis o artritis reumatoide. No se encontró diferencia significativa entre los dos últimos grupos respecto a la viscosidad intrínseca. La concentración del ácido hialurónico en el líquido sinovial de los enfermos con artritis reumatoide fué inferior a la de los enfermos con osteoartritis o artritis traumática, pero no hubo diferencia significativa entre los dos últimos grupos.

No hubo correlación entre la concentración del ácido hialurónico o la viscosidad intrínseca del líquido sinovial y el estado clínico de la enfermedad en los casos de artritis reumatoide.

La viscosidad intrínseca de los líquidos sinoviales recogidos a la necropsia no difería apreciadamente de la viscosidad del líquido sinovial "normal", pero la concentración del ácido hialurónico en los líquidos sinoviales de cadáveres fué marcadamente inferior a la encontrada en voluntarios "normales". 